\title{
Pengaruh Biaya Operasional Terhadap Laba Bersih PT. Ultrajaya Milk Industry \& Trading Company, Tbk
}

\author{
Angelia Putri Yuliani $1^{{ }^{*}}$, Puji Muniarty ${ }^{1^{\star}}$ \\ Program Studi Manajemen, Sekolah Tinggi Ilmu Ekonomi (STIE) Bima \\ JI. Wolter Monginsidi Kompleks Tolobali Kota Bima 84118 NTB \\ ^Email: puji.stiebima@gmail.com
}

Naskah diterima 22 Februari 2021, Revisi 15 Maret 2021, Terbit 29 April 2021

\begin{abstract}
DOI: doi.org/10.21107/pamator.v14i1.10204

This study aims to find out and analyze the effect of operating costs on net profit at PT Ultrajaya Milk Industri \&Trading Company, Tbk. Type of associative research with quantitative approach with the amount of population data for 29 years from 1990-2020, namely audited profit loss report in the form of operational costs and net profit and sampling techniques with purposive sampling for 15 years from 2005-2019. Data in the form of secondary data accessed through the company's official website and data analysis using operational cost and net profit analysis with documentation data collection techniques and library studies. Then continued with the analysis of operating costs and net profit and significance test (two tail test). The results showed that operational costs had a significant impact on net profit at PT. Ultrajaya Mik Industry \&Trading Company, Tbk.
\end{abstract}

Key words: nett income, operating cost, profit, PT. Ultrajaya Milk Industry

\section{PENDAHULUAN}

Revolusi 4.0 era globalisasi semua kegiatan perusahaan dilakukan dengan cara komputerisasi yang tidak terlepas dari koneksi internet. Sarana internet memberikan kemudahan baik perusahaan skala kecil, menengah dan besar untuk menjalin mitra dengan perusahaan lainnya. Sehingga berdampak setiap tahun corporate disuatu negara selalu bertambah untuk setiap periodenya dan persaingan setiap perusahaan pun semakin meningkat.

Perusahaan yang menetapkan tujuan jangka panjang selalu memperbaiki kualitas SDM maupun kualitas produk serta jasa guna memenuhi kebutuhan masyarakat pada umumnya dan konsumen pada khususnya untuk mewujudkan sinergitas tersebut maka seorang manajer keuangan wajib semaksimal mungkin untuk merencanakan dan melakukan pengelolaan kas perusahaan secara efisien dan efektif. Kas merupakan akun akuntansi dalam laporan keuangan yang menunjukan tingkat return laba baik laba bersih maupun laba kotor tanpa menyampingkan biaya operasional perusahaan. Laba bersih merupakan track record kinerja perusahaan. Seperti yang dilansir oleh (Subramanyam,
2014) bahwa laba bersih adalah selisih dari pendapatan dan keuntungan setelah dikurangi dengan beban dan kerugian. Kemudian (Wardiyah, 2017) mengungkapkan bahwa biaya operasional ialah biaya yang menggambarkan sejauh mana efisiensi pengelolaan usaha.

Prestasi perusahaan dapat dilihat dari sajian laporan keuangan yang dipublikasikan secara berperiodik per 31 Desember, laporan keuangan adalah laporan yang menunjukkan kondisi keuangan perusahaan pada saat ini atau dalam suatu periode tertentu (Kasmir, 2014). Namun berbeda yang dungkapkan oleh (Munawir, 2010) bahwa pengertian laporan keuangan terdiri dari neraca dan suatu perhitungan laba-rugi serta laporan mengenai perubahan ekuitas. Neraca tersebut menunjukkan atau menggambarkan jumlah suatu aset, kewajiban dan juga mengenai ekuitas dari suatu perusahaan pada tanggal tertentu. Dengan begitu dapat ditarik suatu kesimpulan bahwa laporan keuangan merupakan daftar berbagai cashflow selama kegiatan operasional perusahaan yang dibuat secara sistematis dan dianalisis dengan berbagai metode yang mendeskripsikan dan menunjukkan kondisi 
keuangan perusaaan itu sendiri di periode tertentu.

Biaya penjualan dan biaya administrasi terdapat hubungan dengan operasi yang dilakukan. Biaya operasional merupakan cost yang dihasilkan oleh suatu perusahaan, oleh sebab itu semakin tinggi tingkat aktivitas perusahaan, maka semakin tinggi juga biaya operasinya, karena biaya operasi adalah pembiayaan langsung kegiatan perusahaan, jadi dalam mengatur biaya operasi dapat dilakukan secara terpisah dengan memberikan aktivitas-aktivitas perusahaan tersebut (Jusuf, 2014). Peningkatan kegiatan operasional perusahaan maka semakin tinggi pula aktivitas yang akan dijalankan sebuah korporasi sehingga berdampak pada tingginya penyerapan biaya yang akan dikeluarkan dalam menunjang kegiatan operasionalnya. Jika perusahaan bisa menekan biaya operasional maka suatu perusahaan tersebut akan dapat meningkatkan laba bersih, begitu juga sebaliknya jika terjadi banyaknya biaya yang dikeluarkan akan mengakibatkan turunnya pendapatan laba. Keseluruhan aktivitas opersional perusahaan semuanya berpusat pada biaya operasional karena hal ini sangat berpengaruh terhadap keputusan ketercapaian tujuan perusahaan itu sendiri.

Laba bersih adalah selisih lebih semua pendapatan dan keuntungan terhadap semua beban dan kerugian (Mokhamad, 2012). Laba bersih adalah selisih lebih semua pendapatan dan keuntungan terhadap semua beban dan kerugian. Menurut (Hery, 2017) menyatakan bahwa laba bersih adalah laba yang berasal dari transaksi pendapatan, beban, keuntungan dan kerugian. Laba bersih dapat diukur dengan selisih laba sebelum pajak dengan pajak penghasilan (Hery, 2017). Dapat disimpulkan bahwa laba bersih merupakan komponen digunakan manajemen perusahaan untuk menilai kinerja perusahaan selama satu tahun dengan melihat selisih laba sebelum pajak dikurangi pajak penghasilan selama periode akuntansi.

PT. ULTJ, Tbk adalah perusahaan yang memproduksi minuman yang berdiri sejak tahun 1958 dengan langkah awal kegiatan dari indutri rumah tangga. seiring sejalan progres marketshare perusahaan PT. ULTJ, Tbk menjadi PT ditahun 1971 dan menjadi pelopor bidang industri minuman dalam kemasan dengan sampai saat ini merupakan salah satu korporasi yang memiliki mesin pemroses minuman tercanggih di Asia Tenggara. Rekam jejak kinerja keuangan dari sisi biaya operasional dan laba bersih PT. ULTJ, Tbk di dekade periode 2005-2019 mengalami fluktuatif. Hal ini tergambar ditahun 2008 biaya operasional mengalami penurunan namun ditahun 2010-2019 mengalami peningkatan sehingga laba bersih ditahun 2013-2017 berada diposisi fluktuatif tetapi ditahun 2009 mengalami penurunan yang cukup signifikan. Berikut merupakan data biaya operasional dan laba bersih pada PT. ULTJ, Tbk. (www.ultrajaya.co.id). Hal ini lah yang mendasari peneliti tertarik menelaah lebih lanjut tentang pengaruh biaya operasional terhadap laba bersih pada PT. ULTJ, Tbk. Berdasarkan hasil analisis dan pengujian atas data yang telah dikemukakan oleh Nurlaela Sari (2020) bahwa biaya operasional terhadap laba bersih memiliki hubungan. Hasil perhitungan positif menunjukkan bahwa terdapat hubungan antara biaya operasional terhadap laba bersih. Sehingga peneliti tertarik untuk meneliti tentang Pengaruh Biaya Operasional terhadap Laba Bersih pada PT. Ultrajaya Milk industry \& trading company, Tbk.

\section{METODOLOGI}

Penelitian dengan jenis asosiatif dengan pendekatan kuantitatif yaitu mencari pengaruh antara biaya operasional terhadap laba bersih. Data dikumpulkan melalui studi pustaka dan dokumentasi. Alat pengumpulan data yang digunakan yaitu daftar tabel berupa data laporan keuangan yang terdiri atas laporan rugi laba meliputi biaya operasional terdiri atas biaya penjualan dan biaya administrasi serta laba bersih terdiri atas laba sebelum pajak dan pajak penghasilan. Sumber data dalam penelitian ini adalah data sekunder annual report PT. ULTJ, Tbk. Populasi penelitian yang digunakan yaitu laporan keuangan rugi laba selama 29 tahun dari tahun 1990-2019 dan sampel penelitian selama 15 tahun (20052019) dengan purposive sampling kriteria ketersediaan data dan up date. Untuk pengolahan data digunakan data time series 
yang dikumpulkan melalui studi pustaka dan dokumentasi.

Uji Statistik dianalisa dengan menggunakan regresi linier sederhana, koefisien korelasi sederhana, koefisien determinasi sederhana dan uji hipotesis menggunakan uji t-2 pihak. Regresi linier sederhana digunakan untuk melakukan prediksi seberapa tinggi nilai variabel dependen bila nilai variabel independen dimanipulasi (dirubah-rubah). Adapun persamaan umum regresi linear sederhana adalah: $Y=a+b x$

Dimana:

$\mathrm{Y}=$ Variabel terikat (Laba bersih)

$\mathrm{a}=$ Konstanta

$\mathrm{b}=$ koefisien variabel

$\mathrm{X}=$ Variabel bebas (Biaya operasional)

Sedangkan koefisien korelasi sederhana digunakan untuk melihat tingkat keeratan hubungan antar variabel yaitu laba bersih terhadap biaya operasional, kemudian koefisien determinasi digunakan untuk melihat kontribusi pengaruh biaya operasional terhadap laba bersih. Untuk mengetahui dan menganalisa secara detail data empirik pengaruh secara signifikan antara biaya operasional terhadap laba bersih maka digunakan uji t-2 pihak dengan alpha yang digunakan sebesar $5 \%$. Adapun kriteria uji t-2 pihak, (1) jika t-hitung > t-tabel maka keputusannya $\mathrm{Ha}$ diterima kemudian HO ditolak, (2) jika t-hitung < t-tabel maka keputusannya $\mathrm{Ha}$ ditolak kemudian $\mathrm{Ha}$ diterima.

\section{HASIL PEMBAHASAN \\ Analisa Laba Bersih}

Setiap perusahaan yang go public di IDX (Indonesia Stock Exchange) secara finansial aset mengharapkan tingkat return yang di proxikan dengan laba bersih dan tidak menutup kemungkinan PT. ULTJ, Tbk semaksimal mungkin meminimalisir biaya operasional yang dikeluarkan untuk setiap produksinya. Laba bersih memiliki nilai ratarata (mean) sebesar 25.7673, laba bersih maximum sebesar 27,67 yang berarti bahwa sampel tertinggi mempunyai tingkat pengaruh informasi sebesar 27,74 dan laba bersih minimum sebesar 21,92 yang berarti bahwa sampel terendah memiliki tingkat pengaruh informasi sebesar $2.192 \%$ dari data tersebut dapat diketahui bahwa laba bersih secara rata-rata (mean) mengalami perubahan laba bersih fluktuatif dengan ratarata return sebesar 25,7673 hal ini menunjukan bahwa selama periode 20052019 secara umum laba bersih PT.ULTJ, Tbk mengalami fluktuasi (Tabel 1).

Tabel 1. Perkembangan Laba Bersih PT. ULTJ, Tbk tahun 2005-2019

\begin{tabular}{cccc}
\hline Tahun & $\begin{array}{c}\text { Laba } \\
\text { sebelum } \\
\text { pajak } \\
\text { (Juta Rp) }\end{array}$ & $\begin{array}{c}\text { Pajak } \\
\text { penghasilan } \\
\text { (Juta Rp) }\end{array}$ & $\begin{array}{c}\text { Laba } \\
\text { bersih } \\
\text { (Juta Rp) }\end{array}$ \\
\hline 2005 & 2.953 & 366 & 2.586 \\
2006 & 9.010 & 2.005 & 7.004 \\
2007 & 53.251 & 14.225 & 39.026 \\
2008 & 399.713 & 61.160 & 338.553 \\
2009 & 31.146 & 4.101 & 27.045 \\
2010 & 202.923 & 95.584 & 107.339 \\
2011 & 156.817 & 28.368 & 128.449 \\
2012 & 457.970 & 104.538 & 353.431 \\
2013 & 436.720 & 111.592 & 325.127 \\
2014 & 374.957 & 91.896 & 283.061 \\
2015 & 700.675 & 177.575 & 523.100 \\
2016 & 932.482 & 222.657 & 709.825 \\
2017 & 1.035 .192 & 316.790 & 718.402 \\
2018 & 949.018 & 247.411 & 701.607 \\
2019 & 1.375 .359 & 339.494 & 1.035 .865 \\
\hline
\end{tabular}

\section{Analisa Biaya Operasional}

Pada umumnya biaya operasional merupakan yang dikeluarkan pada PT. ULTJ, Tbk berupa biaya penjualan dan biaya administrasi umum. Biaya-biaya ini merupakan biaya tetap dikeluarkan untuk setiap melakukan produksi produk. Variabel biaya operasional memiliki nilai rata-rata (mean) sebesar 26,6007, nilai maximum sebesar 27,74 yang berarti bahwa sampel tertinggi mempunyai tingkat pengaruh informasi sebesar $2.774 \%$ sedangkan nilai minimum sebesar 24,80 yang berarti bahwa sampel terendah mempunyai tingkat pengaruh informasi laba bersih sebesar sebesar $2.480 \%$.

Tabel 2. Perkembangan biaya operasional PT. ULTJ, Tbk tahun 2005-2019

\begin{tabular}{cccc}
\hline Tahun & $\begin{array}{c}\text { Biaya } \\
\text { penjualan } \\
\text { (Juta Rp) }\end{array}$ & $\begin{array}{c}\text { Biaya } \\
\text { administrasi } \\
\text { umum (Juta Rp) }\end{array}$ & $\begin{array}{c}\text { Biaya } \\
\text { operasional } \\
\text { (Juta Rp) }\end{array}$ \\
\hline 2005 & 40.165 & 18.540 & 58.705 \\
2006 & 60.066 & 19.581 & 79.647 \\
2007 & 134.231 & 38.879 & 173.110 \\
2008 & 104.408 & 22.996 & 127.404 \\
2009 & 91.176 & 28.180 & 119.357
\end{tabular}




\begin{tabular}{cccc}
\hline Tahun & $\begin{array}{c}\text { Biaya } \\
\text { penjualan } \\
\text { (Juta Rp) }\end{array}$ & $\begin{array}{c}\text { Biaya } \\
\text { administrasi } \\
\text { umum (Juta Rp) }\end{array}$ & $\begin{array}{c}\text { Biaya } \\
\text { operasional } \\
\text { (Juta Rp) }\end{array}$ \\
\hline 2010 & 331.528 & 75.298 & 406.826 \\
2011 & 361.471 & 82.175 & 443.647 \\
2012 & 366.413 & 82.694 & 449.108 \\
2013 & 433.576 & 117.578 & 551.154 \\
2014 & 488.878 & 120.797 & 609.676 \\
2015 & 593.015 & 136.835 & 729.850 \\
2016 & 634.650 & 136.486 & 771.136 \\
2017 & 689.769 & 172.082 & 861.851 \\
2018 & 855.358 & 196.900 & 1.052 .258 \\
2019 & 908.877 & 202.883 & 1.111 .760 \\
\hline
\end{tabular}

\section{Uji Normalitas Data}

Berdasarkan Gambar 1 terlihat bahwa titik-titik ploting mengikuti dan mendekati garis diagonal yang berarti bahwa nilai residual berdistribusi normal. Dengan demikian maka asumsi normalitas untuk nilai residual dalam analisis regresi linear sederhana dalam penelitian ini dapat terpenuhi.

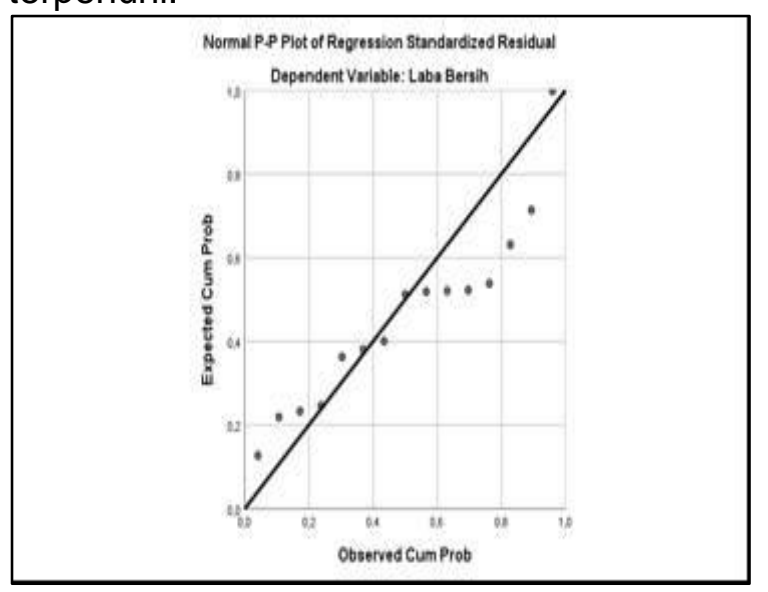

Gambar 1. Normalitas Data P-plot

\section{Uji-t (Two-tailed t test)}

Berdasarkan hasil Uji-t (Tabel 3) dapat dilihat bahwa nilai t hitung $7.489>$ dari t tabel ( $\mathrm{dk}=\mathrm{n}-\mathrm{k}, \mathrm{k}$ dimana $\mathrm{dk}=15-2=13$ sehingga nilai t-tabel sebesar 2,160 dan tingkat signifikan (sig) $<0,05$ yaitu $0,000<0,05$, artinya ada pen garuh yang signifikan antara biaya operasional terhadap laba bersih pada PT. ULTJ, Tbk. Biaya operasional berpengaruh terhadap laba bersih, sehingga dapat disimpulkan bahwa $\mathrm{Ha}$ diterima dan $\mathrm{HO}$ ditolak. Nilai Korelasi bertanda positif, ini berarti terdapat hubungan antara biaya operasional dengan laba bersih. Penelitian ini sesuai dengan teori (Kuswandi 2012) dalam perhitungan laba rugi, besarnya biaya ini akan mengurangi laba atau menambah rugi perusahaan. Selain itu penelitian ini juga didukung oleh penelitian sebelumnya (Risyana, 2018) yang membuktikan bahwa biaya operasional berpengaruh terhadap laba bersih dan apabila semakin tinggi biaya operasional yang ada diperusahaan maka laba bersih akan mengalami penurunan dan juga sebaliknya.

Tabel 3. Hasil Uji-t

\begin{tabular}{|c|c|c|c|c|c|}
\hline \multirow[b]{2}{*}{ Model } & \multicolumn{2}{|c|}{$\begin{array}{l}\text { Unstandardized } \\
\text { Coefficients }\end{array}$} & \multirow{2}{*}{\begin{tabular}{|l} 
Standardized \\
Coefficients
\end{tabular}} & \multirow[b]{2}{*}{$t$} & \multirow[b]{2}{*}{ Sig. } \\
\hline & B & Std. Error & & & \\
\hline (Constant) & -17.698 & 5.808 & & 3.047 & .009 \\
\hline $\begin{array}{l}\text { BIAYA OPERASIONAL } \\
(\mathrm{X})\end{array}$ & 1.634 & .218 & .901 & 7.489 & .000 \\
\hline
\end{tabular}

a. Dependent Variable: LABA BERSIH (Y)

\section{KESIMPULAN}

Berdasarkan hasil analisis dan pengujian atas data yang telah dikemukakan sebelumnya maka kesimpulan penelitian ini adalah biaya operasional berpengaruh signifikan terhadap laba bersih pada PT. ULTJ, Tbk. Saran yang dapat direkomendasi hendaknya perusahan dapat mengatur kembali prencanaan keuangan yang ada jika ditemukan tanda-tanda hasil laba bersih yang menurun di 1 periode prosuksi sehingga perusahaan tetap bertahan dan beroperasi dan diharapkan pula mananajemen perusahaan untuk bisa mengendalikan biaya, peningkatan laba bersih dapat ditimgkatkan lagi dengan lebih adaptif dengan kebutuhan konsumen akan produk yang hendak diproduksi maksudnya disini yaitu lebih peka lagi dalam jumlah barang yang akan diproduksi, kapasitas dan proses, aspek penjualan aspek promosi dan aspek profitabilitas masing-masing segemen usaha.

\section{DAFTAR PUSTAKA}

B.M, Butar. 2018. "Pengaruh Penjualan Terhadap Laba Bersih Pada PT. Biosafe Indonesia Medan." Jurnal Neraca Agung 1:65-67.

Casmadi Y. 2019. "Pengaruh Biaya Produksi Dan Biaya Operasional Terhadap Laba Bersih Pada PT. Ultrajaya Milk Industry \& Trading Company Tbk." Akuntansi 1:14-23.

Harahap, Sofyan. 2011. Teori Akuntansi. pertama ce. Jakarta: rajawali pers. 
Hery. 2017. Kajian Riset Akuntansi. Jakarta: PT. Grasindo.

Jopie jusuf. 2006. Analisis Kredit Untuk Account Officer. Jakarta: gramedia Pustaka Utama.

Jopie jusuf. 2014. Analisis Kredit Untuk Account Officer. Jakarta: PT. Gramedia.

Kasmir. 2014. Analisis Laporan Keuangan. Jakarta: Rajagrafindo Persada.

Kuswandi. 2012. Akuntansi Perbankan. Jakarta: Intitut Bankir Indonesia.

Manda Gusganda. 2018. "Pengaruh Pendapatan Dan Biaya Operasional Terhadap Laba Bersih (Studi Kasus Pada Perusahaan Manufaktur Sektor Industri Dasar Dan Kimia Yang Terdaftar Di BEI Periode 2012-2016." Jurnal Ekonomi Dan Bisnis 8:19-33.

Mokhamad, F. P. 2012. Pengaruh Pendapatan Usaha Dan Beban Pajak Terhadap Prediksi Laba Bersih. Journal Of Accounting.

Munawir, S. 2010. Analisis Laporan Keuangan. Yogyakarta: Liberty.

Nurlaela, Sari. 2020. "Efisiensi Biaya
Operasional Terhadap Peningkatan Laba Bersih." Jurrnal IImu Keuangan Dan Perbankan 9:108-16.

Risyana, Rizki dan Leny Suzan. 2018. "Pengaruh Volume Penjualan Dan Biaya Operasional Terhadap Laba Bersih." EProceeding of Management 5.

Subramanyam. 2014. Analisis Laporan Keuangan. Jakarta: Salemba Empat.

Susilawati, Endang. 2018. "Pengaruh Penjualan Dan Biaya Operasional Terhadap Laba Bersih PT. Indocement Tunggal Prakarsa (Persero) Tbk Periode 2010-2017." Jurnal Saintek Manajemen \& Akuntansi 1:76-87.

Syam Fairuzzaini. 2018. "Pengaruh Pendapatan Dan Biaya Operasional Terhadap Laba Bersih (Studi Kasus Pada Perusahaan Manufaktur Sektor Industri Dasar Dan Kimia Yang Terdaftar Di BEI Periode 2012-2016)." Jurnal Ekonomi Dan Bisnis 8:19-33.

Wardiyah, Mia Lasmi. 2017. Analisis Laporan Keuangan. bandung: Pustaka Setia. 